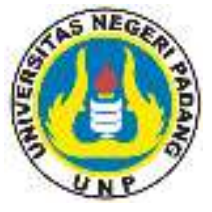

\title{
ANALISIS PEMENDEKAN GAIRAIGO DALAM KOMIK DETECTIVE CONAN KARYA GOSHO AOYAMA CHAPTER 1000-1040
}

\author{
Bestia Dwi Putri ${ }^{1}$, Damai Yani ${ }^{2}$
}

Prodi Bahasa Jepang, Fakultas Bahasa dan Seni, Universitas Negeri Padang ${ }^{1}$ Prodi Bahasa Jepang, Fakultas Bahasa dan Seni, Universitas Negeri Padang ${ }^{2}$ Email Penulis : bestiapyk23@gmail.com

\begin{tabular}{lc}
\hline Sejarah Artikel \\
\hline Submit $: 2020-01-14$ \\
Diterima $: 2020--02-08$ \\
Diterbitkan : 2020-12-11
\end{tabular}

\section{Kata Kunci:}

shortening, gairaigo.

Detective Conan

\begin{abstract}
Abstrak
The purpose of this research to determine the shortening process of gairaigo that found in Detective Conan comics by Gosho Aoyama chapter 1000- 1040. The type of research is qualitative research with descriptive methods. The data used in this research is the absorption vocabulary (gairaigo) that contained in Detective Conan's comics by Gosho Aoyama chapter 1000-1040. The data source taken is shortening of gairaigo in the Detective Conan comic by Gosho Aoyama in chapter 1000-1040. Based on research results from 161 gairaigo data, there were 29 data are gairaigo whose word formation is derived from shortening wich dividen into 7 clipping data consists of 6 back-clipping and 1 fore-clipping, 20 compound truncation consists of 8 morpho-ortographic truncation compound clipping and 4 ellipsis, also 2 data is combination of clipping and ellipsis.
\end{abstract}

\section{PENDAHULUAN}

Bahasa adalah kemampuan yang dimiliki manusia untuk berkomunikasi dengan manusia lainnya dengan menggunakan tanda ataupun kata. Selain itu, bahasa juga digunakan sebagai alat untuk menyampaikan suatu ide, pikiran, gagasan, hasrat, dan keinginan kepada orang lain. Ketika kita menyampaikan ide, pikiram, gagasan, hasrat, dan keinginan kepada seseorang baik secara lisan maupun tulisan, orang tersebut dapat menangkap apa yang kita maksud, tiada lain karena ia memahami makna yang dituangkan melalui bahasa tersebut. Jadi, fungsi bahasa merupakan media untuk menyampaikan suatu makna kepada seseorang baik secara lisan maupun tertulis (Sutedi, 2011:2)

Kemajuan teknologi dan informasi berkembang begitu pesat. Faktor jarak tidak lagi menjadi kendala dalam proses komunikasi, bahkan berlainan bahasa sekalipun. Komunikasi langsung antar masyarakat yang berlainan bahasa, bahkan berlainan budaya, menimbulkan kontak bahasa yang pada akhirnya akan saling memengaruhi. Kontak bahasa ialah saling pengaruh antara dua bahasa atau lebih atau ragam bahasa karena penutur berbagai bahasa tersebut sering berinteraksi. Interaksi-interaksi tersebut menyebabkan terjadinya pencampuran dan penyerapan budaya dan bahasa (Matras, 2009:1) 
Dalam bahasa Jepang penyerapan kata-kata dari bahasa asing biasa disebut dengan gairaigo (外来語). Jika diartikan dari kanjinya, 外 (gai) artinya 'luar', 来 (rai) artinya'datang', dan 語 (go) artinya bahasa, secara keseluruhan dapat diartikan bahasa yang datang dari luar. Gairaigo ditulis menggunakan huruf katakana sehingga sering juga disebut dengan katakana-go. Kata serapan dalam bahasa Jepang banyak diadaptasi dari bahasa yang berasal Eropa Barat. Namun, setelah Restorasi Meiji, sebagian besar kata-kata serapan berasal dari bahasa Inggris

Gairaigo merupakan bagian dari goi (語彙/ kosakata). Berdasarkan asal usulnya, kosakata bahasa Jepang dapat dibagi menjadi empat macam yakni wago (和語/ kosakata asli bahasa Jepang, sering juga disebut sebagai yamato kotoba, ditulis dengan huruf hiragana dan kanji), kango (漢語/ kosakata pinjaman dari bahasa China, sering juga disebut sebagai Sino-Japanese, ditulis dengan huruf kanji), gairaigo ( 外来語/ kosakata pinjaman dari bahasa Inggris dan bahasa asing lain selain bahasa China, ditulis dengan huruf katakana) dan konshugo ( 混種語 / kosakata campuran/gabungan, yang merupakan kombinasi dari wago, kango dan gairaigo, ditulis dengan hiragana, kanji dan katakana (Coulmas, 2004: 99).

Sudjianto dan Dahidi (2004: 104) menyatakan terdapat beberapa karakteristik gairaigo, diantaranya adalah:

a) Silabel tertutup pada kata bahasa asing yang akan dijadikan gairaigo harus diubah menjadi silabel terbuka dengan cara menambahkan.

b) bunyi vokal pada setiap konsonan pada silabel tertutup tersebut. Hal ini yang menjadikan gairaigo tertentu terasa panjang maka tidak sedikit gairaigo yang dipendekkan sehingga terkesan lebih praktis dan mudah digunakan. Contohnya コネクション(konekushon, koneksi) dipendekkan menjadi コネ (kone).

c) Penambahan kelas kata pada gairaigo Di dalam pemakaian gairaigo ada beberapa kelas kata nomina dan adjectiva yang berubah menjadi verba, contohnya サボ(sabo) + る(ru) menjadi サボる(saboru).

d) Penambahan sufiks "na" pada gairaigo kelas kata adjectiva agar menjadi jelas bahwa gairaigo tersebut termasuk kelas kata adjectiva-na bukan sebagai adjectiva-i. Contohnya ハンサム (hansamu) menjadi ハンサムな (hansamuna).

e) Pergeseran makna pada gairaigo Sejalan dengan perkembangan pemakaiannya, ada gairaigo yang memiliki makna terbataspada makna kata aslinya dan ada juga gairaigo yang mengalami pergeseran makna darimakna kata aslinya. Contohnya ミシン(mishin) pada mulanya berarti mesin (機会 ,kikai). Tetapi sekarang kata mishin yang terbatas pada kikai dipakai juga untuk mesin jahit.

Berdasarkan uraian diatas, gairaigo memiliki beberapa karakteristik seperti pemendekan gairaigo, pergeseran makna gairaigo, penambahan sufiks-na dan perubahan kelas kata. Dari sekian banyaknya karakteristik gairaigo pemendekan gairaigo adalah salah satu penelitian yang menarik, apabila gairaigo sudah mengalami pemendekan, maka pembelajar bahasa Jepang akan sulit mengartikan dan memahami arti dari gairaigo tersebut. Maka dengan adanya penelitian ini, pembelajar akan 
memahami proses pemendekan gairaigo sehingga pembelajar dapat mepahami arti dari gairaigo tersebut. Gairaigo yang telah dipendekkan, tidak akan ditemukan didalam kamus. Contohnya saja pada kata マスコミ (masukomi), merupakan pemendekan dari kata マスコミュニケーション (masukomyunikeeshon/mass communication), jika dilihat pada kamus kata マス コミ (masukomi) tidak akan ditemukan. Hal ini tentu saja akan menjadi kesulitan tersendiri bagi pembelajar bahasa Jepang.

Engman (2018) proses pemendekan dapat terjadi pada satu kata (single word truncation) dan kata gabungan (compound truncation). Single word truncation juga sering disebut dengan clipping. Menurut Irwin (2016) clipping (pemendekan pada satu kata) terdiri atas back-clipping (pemendekan pada akhir kata), fore-clipping (pemendekan pada awal kata), dan mid-clipping (pemendekan pada tengah kata). Sedangkan pemendekan pada kata gabungan (compound truncation) terdiri atas morphoortographic truncation (pemendekan dengan menghilangkan semua huruf kecuali huruf pertama kata), compound clipping (mengurangi bagian leksem dari kata gabungan), dan ellipsis (menghilangkan salah satu elemen dari gabungan kata).

Dewasa ini dalam masyarakat Jepang, khususnya kawula muda, banyak menggunakan gairaigo dalam keseharian mereka. Sebagai bukti yang nyata, gairaigo banyak dijumpai dalam majalah-majalah anak muda yang beragam jenisnya, bukubuku, novel, komik, maupun film-film yang semakin marak diproduksi. Salah satunya adalah komik Detective Conan karya Gosho Aoyama. Komik Detective Conan merupakan komik yang sangat populer tidak hanya dimasa sekarang, komik ini sudah populer semenjak tahun 2000-an. Karena para tokoh umumnya merupakan kaula muda, dan agar komik tersebut terkesan lebih trendy maka gairaigo banyak digunakan dalam komik ini, Dalam skripsi ini, penulis akan menganalisa pemendekan gairaigo yang terdapat pada komik Detective Conan karya Gosho Aoyama chapter 1000- 1040 berdasarkan teori Mark Irwin. Penulis ingin mengetahui apa saja klasifikasi pemendekan gairaigo yang terdapat dalam komik Detective Conan karya Gosho Aoyama chapter 1000-1040.

\section{METODE PENELITIAN}

Penelitian ini merupakan jenis penelitian kualiatif. Sutedi (2011:23) menjelaskan penelitian kualitatif adalah penelitian yang datanya bukan berupa angka-angka dan tidak perlu diolah dengan menggunakan metode statistik. Penelitian ini dikatakan sebagai penelitian kualitatif karena menggunakan data deskriptif berupa kata-kata baik tulisan maupun lisan bukan berupa data yang berbentuk angka-angka.

Metode dari penelitian ini adalah metode penelitian deskriptif. Menurut Sugiyono (2009:63), metode penelitian deskriptif adalah suatu metode yang digunakan untuk meneliti status kelompok manusia, suatu objek, suatu kondisi, suatu sistem pemikiran ataupun suatu strata, peristiwa pada masa sekarang (ketika penelitian sedang berjalan). Langkah dalam penelitian ini adalah mendefinisikan dengan jelas dan spesifik tujuan yang akan dicapai, merancang pendekatanya, mengumpulkan data dan menyusun laporan.

\footnotetext{
${ }^{1}$ Mahasiswa Prodi Pendidikan Bahasa Jepang FBS UNP lulus pada tanggal......

${ }^{2}$ Dosen Prodi Pendidikan Bahasa Jepang FBS UNP
} 
Data dalam penelitian ini yaitu kosakata berupa gairaigo dalam komik Detective Conan karya Gosho Aoyama. Sumber data utama dalam penelitian ini adalah komik Detective Conan karya Gosho Aoyama chapter 1000-1040. Instrumen dalam penelitian ini adalah peneliti itu sendiri. Adapun teknik pengumpulan data sebagai berikut. Pertama, Membaca komik Detective Conan karya Gosho Aoyama chapter 1000-1040 dan memahaminya. Kedua, Mengidentifikasi kosakata yang merupakan gairaigo dan menuliskannya pada kartu data. Ketiga, Mencatat semua kosakata yang merupakan gairaigo ke dalam tabel inventaris data

\section{HASIL DAN PEMBAHASAN}

Berdasarkan data yang ditemukan dalam komik Detective Conan karya Gosho Aoyama chapter 1000-1040, ditemukan data gairaigo sebanyak 161 data. Dalam 161 data tersebut, 29 diantaranya merupkan gairaigo yang terbentuk dari pemendekan dengan klasifikasi 7 data clipping yang terdiri dari 6 data backclipping dan 1 data fore-clipping, 20 data compound truncation yang terdiri dari 8 data morpho-ortographic truncation 8 data compound clipping dan 4 data ellipsis, dan terakhir ada 2 data yang merupakan gabungan clipping dan ellipsis

1. Clipping

Clipping merupakan pemendekan yang terjadi pada satu kata. Clipping terbagi atas :

a. Back-clipping, yaitu pemendekan beberapa mora pada bagian akhir kata dan meninggalkan bagian awal kata tersebut. Dari 29 data pemendekan gairaigo terdapat 6 data yang pembentukanya dari backclipping yaitu : アップ(Appu), ダイヤ(Daiya), パニ(Pani), トイ レ(Toire), コンビ(Konbi), マイク (Maiku). Analisis datanya pada kelompok ini yaitu dijabarkan sebagaimana berikut :

Data (1)

アップ

Appu

Pada data (1) terdapat kata アップ(appu), merupakan pemendekan dari kata アップロード(appuroodo) yang penyerapannya berasal dari kata bahasa Inggris yaitu 'upload'. Dalam bahasa Indonesia kata 'upload' bermakna unggah dan atau transfer data. Kata アップロード (apporoodo) terdiri dari 6 mora yakni ' $a$ ', ' $p$ ', ' $p u$ ', 'ro' ' $o$ ' dan ' $d o$ ' mengalami pemangkasan sebanyak 3 mora pada akhir kata, yaitu 口 (ro) 一 (o) dan ド(do) sehingga terbentuklah kata アップ(appu).

b. Fore-clipping, yaitu pemangkasan pada bagian awal kata dan meninggalkan (2 hingga 4 mora) dari bagian akhir kata tersebut. Dari 29 data pemendekan gairaigo yang ditemukan, 1 data diantaranya 
diklasifikasikan sebagai fore-clipping. Data tersebut yaitu : メット (Metto). Analisis data untuk kelompok ini sebagai berikut :

c.

Data (7)

メット

Metto

Pada data (7) ada kata メット(metto), terbentuk dari pemangkasan kata ヘルメット (herumetto) yang merupakan kata serapan dari bahasa Inggris yaitu 'helmet' bermakna helm dalam bahasa Indonesia.

c. Mid-clipping, pemendekan terhadap bagian tengah kata tersebut, sehingga meninggalkan bagian awal dan akhir dari kata. Mid-clipping merupakan bentuk pemendekan yang paling jarang ditemukan, pada penelitian ini tidak ditemukan data mid-clipping

\section{Compound Truncation}

Compound truncation merupakan pemendekan pada kata gabungan, terdapat tiga jenis compound truncation yang terdiri dari :

a. morpho-ortographic truncation, yaitu elemen gabungan dari kata bahasa Inggris dipendekkan dengan menghilangkan semua huruf, kecuali huruf awal dari kata gabungan tersebut, dan ditulis dengan Alfabet Romawi. Dari 29 data pemendekan gairaigo terdapat 8 data yang merupakan morpho-ortographic truncation yaitu SNS (Social Networking Site), AD (Assistant Director), DVD (Digital Vidio Dist), OL (Office Lady), WC (Water Closet), PET (Polylethine Etilen Tephalate), TV (Television), OK (Oll Korrect). Analisis data untuk kelompok ini sebagai berikut :

Data (8)

SNS Social Networking Site

Pada data (8) terdapat huruf SNS singkatan dari kata Social Networking Site yang merupakan pemendekan elemen gabungan dari kata bahasa Inggris dipendekkan dengan menghilangkan semua huruf, kecuali huruf awal dari kata gabungan Social Networking Site sehingga disingkat menjadi SNS. SNS merupakan sebuah web berbasis pelayanan yang memungkinkan penggunanya membuat profi, melihat list pengguna yang tersedia serta mengundang dan menerima teman. Dalam bahasa Indonesia SNS bermakna sama dengan jejaring sosial seperti Facebook, Instagram, twitter, path, dan sejenisnya.

b. Compoud clipping, yaitu kata yang dihasilkan dengan mengurangi bagian dari leksem pembentuk kata majemuk. Biasanya salah satu bagian leksem dari kata majemuk tersebut tetap utuh dan terkadang kedua leksem pembentuk kata majemuk tersebut mengalami pemangkasan. Dari 29 data 
pemendekan gairaigo yang ditemukan terdapat sebanyak 8 data yang merupakan compound clipping yaitu : マスコミ(Masukomi), フルツサ ンド (Furuutsusando), エアマット(Eamatto), イメトレ(Imetore), メッ セジアプリ(Messeejiapuri), スマホ(Sumaho), メールアド (Meeruado), ハンカチ (Hankachi). Analisis data pada kelompok ini sebagai berikut :

Data (16)
マスコミ

Masukomi

Pada data (16) terdapat kata マスコミ(masukomi) merupakan pemendekan dari kata マスコミュニケーション (masukomyunikeeshon) yang penyerapan katanya berasal dari kata bahasa Inggris 'mass communication'. Dalam bahasa Indonesia kata 'mass communication' bermakna komukasi massa atau lebih tepatnya media massa. Kata マスコミ(masukomi) terbentuk dari pemangkasan yang salah satu leksemnya tetap utuh, yaitu leksem マス(masu) tetap utuh sedangkan leksem コミュニケーション (komyunikeeshon) mengalami pemangkasan 4 mora terakhir sehingga menjadi コミ(komi).

c. Ellipsis adalah pemendekan dengan menghilangkan salah satu elemen kata dari gabungan kata. Dari 29 data pemendekan gairaigo yang ditemukan, terdapat 4 data yang merupakan ellipsis yaitu : ノート (Nooto), リ ユツク $($ Ryukku), コンタク ト (Kontakuto), メイク (Meiku) . Analisi data pada kelompok ini sebagai berikut : Data (24) ノー 卜 Nooto Pada data (24) terdapat kata ノート (nooto) merupakan pemendekan dari kata ノートブック (nooto bukku) yang penyerapan katanya berasal dari kata bahasa Inggris yaitu kata 'note book' . Dalam bahasa Indonesia kata 'note book' bermakna buku catatan, buku tulis atau buku agenda. Kata ノート (nooto) terbentuk dengan menghilangkan elemen kata akhir, yaitu book dari kata majemuk note book (ノートブッ ク /nooto bukku).

Data (24)

ノート

Nooto

Pada data (24) terdapat kata ノート (nooto) merupakan pemendekan dari kata ノートブック (nooto bukku) yang penyerapan katanya berasal dari kata bahasa Inggris yaitu kata 'note book' . Dalam bahasa Indonesia kata 'note book' bermakna buku catatan, buku tulis atau buku agenda. Kata ノート (nooto) terbentuk dengan menghilangkan elemen kata akhir, yaitu book dari kata majemuk note book (ノートブック /nooto bukku). 


\section{Gabungan clipping dan ellipsis}

Pada 29 data pemendekan gairaigo yang ditemukan, terdapat sebanyak 2 data yang proses pembentukannya dari gabungan jenis pemendekan clipping dan ellipsis yaitu : ネット (netto), コンビニ (konbini). Analisis data diatas sebagai berikut:

Data (28)

ネット

Netto

Pada data (28) terdapat kata ネット(netto) merupakan pemendekan dari kataインターコネクション.ネットワーキング (intaakonekushon nettowaakingu) yang penyerapan katanya berasal dari bahasa Inggris yaitu kata 'interconnection networking'. Kata 'interconnection networking' sering disingkat menjadi internet. Dalam bahasa Indonesia kata internet berarti jaringan komunikasi elekronik yang menghubungkan jaringan komputer dan fasilitas komputer yang terorganisasi diseluruh dunia melalui telepon atau satelit. Kata ット (netto) terbentuk dari pemangkasan salah satu leksem yaitu leksem ネッ トワーキング (nettowaakingu) dipangkas sebanyak 5 mora menjadi ネッ ト (netto) dan leksem インターコネクション (intaakonekushon) dihilangka

\section{Pembahasan}

Berdasarkan analisis data di atas, peneliti menemukan sebanyak 161 data gairaigo pada komik Detective Conan karya Gosho Aoyama chapter 1000- 1040. Dari 161 data gairaigo tersebut, terdapat 29 data gairaigo yang terbentuk dari pemendekan . Dengan klasifikasi clipping sebanyak 7 data yang terdiri dari 6 data back-clipping dan 1 data fore-clipping, 20 data compound truncation yang terdiri dari 8 data morphoortographic truncation, 8 data compound clipping dan 4 data yang termasuk ellipsis, dan terakhir ada 2 data yang merupakan gabungan clipping dan ellipsis. Berdasarkan data di atas dapat diketahui bahwa data yang paling banyak ditemukan terdapat pada klasifikasi compound truncation sebanyak 20 data,dan data yang tidak ditemukan data yang terdapat pada klasifikasi mid clipping. Dan terdapat beberapa data yang termasuk ke dalam beberapa gabungan klasifikasi, seperti gabungan clipping dan ellipsis sebanyak 2 data. Jika dilihat lagi penelitian relevan, yaitu penelitian yang dilakukan oleh Putri (2019) dengan judul penelitian "Pemendekan Gairaigo dalam J Bridge Bestia Dwi Putri, Damai Yani 49 for Beginners Vol 1 dan 2" . Hasil dari analisis pada buku J-Bridge for Beginners 1 dan 2, terdapat 25 data gairaigo yang pembentukan katanya dari pemendekan, yaitu 6 data clipping, 5 data Compound Clipping, 2 Data morpho-ortographic truncation, 9 data Ellipsis, 3 data clipping dan ellipsis. Hasil penelitiannya terdapat perbedaan, pada penelitian relevan data terbanyak terdapat pada klasifikasi ellipsis, namun pada penelitian ini data terbanyak ditemukan pada klasifikasi morpho-ortographic truncation dan compound clipping. Dan pada penelitian ini ditemukan data yang merupakan fore-clipping yang tidak ditemukan pada penelitian relevan. 


\section{KESIMPULAN}

Berdasarkan analisis data dan pendataan pada komik Detective Conan karya Gosho Aoyama chapter 1000-1040, peneliti menemukan sebanyak 161 data gairaigo. Dari 161 data gairaigo tersebut, terdapat 29 data gairaigo yang terbentuk dari pemendekan berdasarkan teori yang dikemukan oleh Irwin (2016:170). Dengan klasifikasi clipping sebanyak 7 data yang terdiri dari 6 data back-clipping dan 1 data fore-clipping, 20 data compound truncation yang terdiri dari 8 data morphoortographic truncation, 8 data compound clipping dan 4 data yang termasuk ellipsis, dan terakhir ada 2 data yang merupakan gabungan clipping dan ellipsis. Berdasarkan hal tersebut diketahui bahwa data terbanyak yang ditemukan yaitu morpho-ortographic truncation dan compound clipping. Baik pada buku teks, majalah, maupun pada komik gairaigo yang pembentukannya dari pemendekan sangat banyak ditemukan

\section{REFERENSI}

Agnesiyoksih, Yora dan Yulia, Nova dan Zalman, Hendri. 2017. "Penguasaan Gairaigo Mahasiswa Tahun Masuk 2014 Pendidikan Bahasa Jepang Universitas Negeri Padang Jurnal omiyage

http://omiyage.ppj.unp.ac.id/index.php/omiyage/article/view/, diakses 16 Agustus 2019.

Aldiansyah, M. Okky. 2018. "Analisis Penggunaan Kata Serapan (Gairaigo) pada Komik The Psycho Doctor Karya Agi Tadashi dan Matoba Ken Jilid 8". Skripsi. Universitas Sumatera Utara

Arikunto, Suharsimi. 2010. Prosedur Penelitian Sautu Pendekatan Praktik. Jakarta: Rineka Cipta

Coulmas, Florian. 2004. Language Adaptation. Journal of Cambridge: Cambridge University Press

Echols, M.John., dan Hassan Shadily. 2014. Kamus Inggris-Indonesia. Jakarta: Gramedia

Engman, Axel Bergman. 2018. "Loanword Compound Truncation in Japanese A study on Japanese learners' understanding of loanword abbreviations". Thesis. Lund University

Irwin, Mark. 2011. Mora clipping of Loanwords in Japanese. Journal Of Japanese Linguistik, 27(1), pp. 72-82 https://scholar.google.com/scholar?hl=id\&as_sdt=0\%2C5\&q=mark+irwin +the+morphologi+of+loanword\&btnG=\#d+gs_qabs\&u=\%23p\%3DfDq9B K2fay8j, diakses 20 Agustus 2019.

Irwin, Mark. 2016. The morphology of English loanwords. Lexicon and vocabulary items. In Kageyama, Taro and Kishimoto, Hideki (ed.) Handbook of Japanese Lexicon and Word Formation. Berlin/Boston: Mouton de Gruyter.p.161-192

Iori, Isao dkk. 2000. Shokyuu wo Oshieru Hito no tame no Nihongo Bunpou Hando Bukku. Tokyo: 3A Corporation. https://doi.org/10.2991/assehr.k.200306.046

Kamus Besar Bahasa Indonesia https://kbbi.web.id/buku,diakses 4 Oktober 2019

Maharani, Tia Prita. 2015. "Penyingkatan Kata pada Wasei-eigo dalam Kamus Katakana-go Shinjiten Kaiteisanban (カタカナ語新辞典 改訂三版 ).” Jurnal Imiah Mahasiswa FIB 
1.6. https://scholar.google.com/scholar?hl=en\&as_sdt=0\%2C5\&q=maharani+ tia+prita\&btnG=, diakses 20 Agustus 2019.

Maylita, Deasy dkk. 2017. Pemendekan Pada Kata Pinjaman (Gairaigo) Pada Bahasa Jepang. Jurnal online Mahasiswa Online Fakultas Keguruan dan Ilmu Pendidikan Universitas Riau, 4(2), pp.1-11 https://scholar.google.com/scholar?hl=id\&as_sdt=0\%2C5\&q=pemendekan +pada+kata+pinjaman+pada+bahasa+jepang \&btnG=\#d+gs_qabs\&u=\%23 p\%3Dh0_DF9dcqHgJ, diakses 19 Agustus 2019.

Moleong, Lexy J. 2011. Metode Penelitian Kualitatif. Bandung: PT. Remaja Rosdakarya

Putri, Meira Anggia. 2019. Pemendekkan Gairaigo dalam J Bridge for Beginners Vol 1 dan 2. Journal Of Literature Japanese Language Education And Linguistic, 3(1), pp.11-23

Riana, Friska Ratzan. 2018. “Analisis Penggunaan Gairaigo Dalam Lirik Lagu Mr. Chu Karya

Shoko Fujibayashi”. Skripsi. Universitas Sumatera Utara.

https://scholar.google.com/scholar?hl=en\&as_sdt=0\%2C5\&q=riana+r+analisis+pengg unaan+gairaigo\&btnG=, diakses 12 Juli 2019

Saifudin, Akhmad. 2017. Penggunaan Manga Humor dalam Pembelajaran Bahasa Jepang. Jurnal Pendidikan dan Pengajaran Bahasa Jepang, 2(2), pp. 99-113 diakses 28 September 2019.

Soelistyowati, Diah. 2010. Pembentukan Kata Pinjaman (Gairaigo) Dalam Bahasa Jepang. Jurnal Online Universita Dian Nuswantoro, 6(2), pp. 152- 171, diakses 20 Agustus 2019

Sudjianto dan Dahidi. 2004. Pengantar Linguistik Bahasa Jepang. Jakarta: Kesaint Blanc

Sudjianto dan Dahidi. 2009. Pengantar Linguistik Bahasa Jepang. Jakarta: Kesaint Blanc

Sutedi, Dedi. 2011. Dasar-dasar Linguistik Bahasa Jepang. Humaniora. Bandung

Subroto, Edi. 1992. Pengantar Metoda Penelitian Linguistik Struktural. Surakarta: Sebelas Maret University Pres

Sugiyono. 2009. Metode Penelitian Pendidikan. Bandung : Alfabeta 2017. Metode Penelitian Pendidikan. Bandung: Alfabeta

Taniguchi, Goro. 2011. Kamus Standar Bahasa Jepang-Indonesia. Jakarta: Dian Rakyat

Yani, D., 2018. Proses Pembentukkan Gairaigo dalam Buku Teks Minna no Nihongo: Kajian Morfologi. Journal of Japanese Language Education and Linguistics, 2(2), pp.238-248. http://journal.umy.ac.id/index.php/jjlel/article.view/5313, diakses 20 Agustus 2019

Zaim,M. 2014. Metode Penelitian Bahasa. Padang: FBS UNP Press.

Zalman, Hendri. Kosakata Bahasa Jepang Dasar. Padang. Sukabina Pres 